\title{
The viral etiology of cervical cancer: epidemiological evidence
}

The evidence relating human papillomavirus (HPV) infections to cervical cancer includes a large and consistent body of studies indicating a strong and specific role of the viral infection in all countries where investigations have taken place. The association has been recognized as causal in nature by a number of international review parties since the early $90^{\prime} \mathrm{s}^{1-3}$.

Nucleic Acid Amplification Techniques (NAT) regularly identifies HPV DNA in $90 \%-95 \%$ of the cervical cancer specimens both squamous cell and adenocarcinomas. Detailed investigations of the few cervical cancer specimens that appear as HPV DNA negatives in every series has been conducted and the results strongly suggest that these are largely false negatives. The reasons of non-detection are attributable to: a) poor quality of the specimen, poor preservation or absence of cancer tissue; b) HPV DNA integration into cellular DNA with increased target fragmentation, and C) NAT technology, notably length and target sequences of the $\mathrm{B}$ globin probes and of the HPV type specific probes ${ }^{4,5}$.

\section{HPV TYPES}

Of the more than $35 \mathrm{HPV}$ types found in the genital tract, some 10 (HPV types 16, 18, 31, 33, $35,45,51,52,58$ and 59) have been adequately evaluated as high risk types in relation to invasive cervical cancer. For all of them, risk estimates were greater than 30 (range: 35-350) strongly suggesting that these associations are causal in nature ${ }^{6}$.

HPV 16 accounts for some 50\% to $60 \%$ of the cervical cancer cases in most countries, followed by HPV 18 (10\%-12\%) and HPV 31 and 45 (4\%5\% each). Cervical adenocarcinomas showed a slightly different distribution and the most common types are HPV 16 (some 45\%), HPV 18 (some $40 \%$ ) and HPV 45 and 59 ( $4 \%-5 \%$ each).

In series of women without cervical lesions (corresponding to controls in most case control studies or ad-hoc HPV prevalence surveys from the general population) the HPV type specific distri- bution embraces a much larger series of viral types. HPV 16 remains again the most common type (some 20\%) followed by HPV 18 (some 10\%), HPV 45 (some 8\%), HPV 59 (some 2\%) and smaller proportions of some 30 additional HPV types. Many of these rare types are occasionally found in controls and still convey a high risk for cervical cancer ${ }^{6,7}$.

It is of interest to notice that the geographical variation in type distribution has not been fully documented. Some recent studies from areas where little work has been done in the past suggest that some additional variability could be expected. For example, high rates of HPV 35 and 58 in the general population in Mozambique is now being reported ${ }^{8}$. New technical developments are also describing high frequencies of multiple HPV infections that were most probably undetected by previous testing systems (J. Kornegay special contribution, personal communication).

Finally, studies on HPV variants (variation within HPV types affecting down to one nucleotide of the viral genome) are beginning to unveil that the risk of some HPV 16 variants (non-european like) may differ from that of the HPV 16 European prototy$\mathrm{pe}^{9,10}$. The geographical distribution of HPV variants is still being described and its relevance for HPV testing and for vaccine developments is still uncertain.

\section{COHORT STUDIES}

Cohort studies have consistently shown that HPV infections precede by some 10-15 years the development of cervical cancer. In addition to HPV DNA detection, additional markers of neoplastic progression includes HPV type, estimates of the viral load, persistency of the viral detection (as determined by repeated sampling), viral integration and possibly the presence of other environmental factors. The role of host factors in the final prognosis of HPV infections is less well characterized. Most importantly, close follow up of cohorts of women investigated as to their HPV 
status have established that: a) the presence of HPV DNA is necessary for the development and persistency of cervical neoplasm, and b) that disappearance of the viral DNA predicts regression of the neoplastic cells ${ }^{11-15}$ even at a stage of high grade squamous intraepithelial lesions (HGSIL) (Meijer et al 2001, personal communication). The identification of the subset of HGSIL that are scheduled to spontaneous regression may prove to be of substantial importance in the evaluation of screening methods and tests. Additional markers may be developed that provide information on morphologically identical lesions with opposite progmosis. To this respect, viral load, viral integration or markers of viral and cellular genetic interaction may prove to be of value.

Understanding of the time intervals of transient infections is likely to be of critical importance to define how best to use HPV testing in screening programs. From various sources it has been estimated that the mean duration of transient infections for most high risk viral types seems to follow a normal distribution with averages is in the order of 8 months and that HPV16 may perhaps double this interval. This seems to be consistent in both high risk and low risk countries ${ }^{12,13,16}$.

cohort studies are also indicating that infection with one HPV type does not confer protection against novel infections with philogenetically related HPV types or with other HPV types ${ }^{17,18}$.

\section{CASE CONTROL STUDIES}

The International Agency for Research Cancer (IARC) research program on HPV organized a series of case control studies in different countries, mostly in areas at high risk for invasive cervical cancer. To date, this represents the largest data set on invasive cancer in high-risk countries and a major source of reference data.

Preliminary results on the pooled analyses of studies in nine countries, including some 2,288 invasive squamous cell carcinomas, 141 adenocarcinomas and 2,513 matched controls were presented at the $18^{\text {th }}$ International Papillomavirus Conference ${ }^{19}$. The adjusted odds Ratios (the factor by which the risk of cervical cancer of a given woman is multiplied if HPV DNA is detected) for HPV DNA detection was $\mathrm{OR}=83.3$ (95\% CI: 54.9105.3). Type specific risk estimates were as follows: $\mathrm{HPV} 16, \mathrm{OR}=182 ; \mathrm{HPV} 18, \mathrm{OR}=231 ; \mathrm{HPV} 45$, $\mathrm{OR}=148 ; \mathrm{HPV} 31, \mathrm{OR}=71.5 ; \mathrm{HPV} 33, \mathrm{OR}=77.6$; $\mathrm{HPV}$ 35， OR $=34.8 ; \mathrm{HPV} 51 ， \mathrm{OR}=42.7 ; \mathrm{HPV}$ 52, $\mathrm{OR}=145.7 ; \quad \mathrm{HPV}$ 58， $\mathrm{OR}=78.9 ; \quad \mathrm{HPV} 59, \quad \mathrm{OR}=$ 347.3. The estimates of the attributable fraction $(\mathrm{AF} \%)$ (the proportion of disease that is related to HPV DNA) in most studies range from $90 \%$ to
$98 \%$.

The magnitude and the consistency of these estimates indicate that the association is one of the strongest identified for any human cancer making the case for claiming a necessary cause of the disease (i.e. that HPV negative cervical cancer cases are extremely rare) ${ }^{5}$.

\section{HPV AND PRE INVASIVE CERVICAL NEOPLASM}

In developed countries and in areas where screening programs are operational, invasive cervical cancer is a relatively rare disease and most diagnosis are achieved at earlier stages (i.e. carcinoma in situ, HGSIL or cervical intraepithelial neoplasia III-CIN III). Several studies in both developed and developing countries have also shown that HPV is related to these precursor lesions with the same strength (as measured by the magnitude of the $\mathrm{OR}$ ) than the more advanced invasive cancers ${ }^{20-26}$. As the HPV detection methods developed, the prevalence of HPV DNA in low and high grade squamous intraepithelial lesions (LGSIL/HGSIL) increased steadily to levels of $80 \%-$ $90 \%$. In fact, the very high prevalence observed in recent studies promoted the notion that HPV testing would not be suitable for triage of LGSIL (atypical squamous cells of undetermined significance/lowgrade squamous intraepithelial lesions triage studyALTS study group). A substantial part of the variability observed across studies is related to variability in the definition of the pre neoplastic lesions rather than variability in HPV testing.

\section{OTHER RISK FACTORS FOR CERVICAL DYSPLASIA AND CERVICAL CANCER}

Before HPV was investigated, epidemiological studies identified a series of factors as being more prevalent in cases of cervical cancer than in their control groups. This was the case for different sexual and reproductive behavioral traits, use of oral contraceptives (OC), smoking or history of venereal infections, typically herpes virus type 2. The OR observed for such associations were in the range 1 to 3 and the results were inconsistent across studies. Having unveiled the very strong associations with HPV, all these putative additional factors require reevaluation.

Most investigators have attempted such reevaluation by restricting the comparison of the relevant exposures in cases of cervical cancer, most of which were shown to be HPV-positive, with their HPV-positive controls (women in the same age groups from the same underlying population, with HPV infection but without cancer). Preliminary results of the case control studies 
included in the IARC program were reported at the $18^{\text {th }}$ International Papillomavirus Conference. Long term use of OC was identified as an environmental risk factor for HPV infected women. According to these results, users of OC for 5+ years and HPV DNA positive are at a 4-fold increased risk that equally HPV exposed women without OC exposure. The results are equally valid for cervical adenocarcinoma ${ }^{19}$. Other factors that probably play a role are exposure to HIV infections and advanced immunosupression ${ }^{27}$, therapeutic immunosupression post transplant, exposure to Chlamydia trachomatis $^{28}$ and smoking.

\section{References}

1. Muñoz N, Bosch FX, Shah $\mathrm{KV}$, Meheus $\mathrm{A}$, editors. The epidemiology of human papillomavirus and cervical cancer. IARC Scientific Publications No. 119. Lyon: International Agency for Research on Cancer; 1992.

2. IARC monographs on the evaluation of carcinogenic risks to humans. Vol. 64. Human Papillomaviruses. Lyon: International Agency for Research on Cancer; 1995.

3. NIH Consensus Development Panel. National Institutes of Health Consensus Development Conference Statement: Cervical Cancer; 1996 April 1-3. J Natl Cancer Inst Monogr. 1996;21:7-13.

4. Bosch FX, Manos MM, Muñoz N, et al. Prevalence of human papillomavirus in cervical cancer: a worldwide perspective. J Natl Cancer Inst 1995;87:796-802.

5. Walboomers JM, Jacobs MV, Manos MM, et al. Human papillomavirus is a necessary cause of invasive cervical cancer worldwide. J Pathol 1999;189:12-9.

6. Muñoz N, Bosch FX, Chichareon $S$, et al. A multinational case-control study on the risk of cervical cancer linked to $25 \mathrm{HPV}$ types: which are the high-risk types? In: Castellsagué $\mathrm{X}$, Bosch $\mathrm{FX}$, De Sanjosé $\mathrm{S}$, Moreno V, Ribes J, edi- tors. $18^{\text {th }}$ Itemational Papillomavirus Conference-Program and abstracts book. Barcelona: Thau, SL; 2000. p. 125. Available from: URL: http://www. hpv2000.com.

7. Bosch FX, Muñoz N, Chichareon S, et al. HPV and cervical adenocarcinoma: an IARC based multicentric case-control study. In: Castellsagué X, Bosch FX, de Sanjosé $\mathrm{S}$, Moreno V, Ribes $\mathrm{J}$, editors. $18^{\text {th }}$ Intemational Papillomavirus Conference - Program and abstracts book. Barcelona: Thau, SL; 2000. p. 131. Available from: URL: http://www.hpv2000.com.

8. Castellsagué $\mathrm{X}$, Menéndez $\mathrm{C}$, Loscertales MP, et al. Human papillomavi-rus genotypes in rural Mozambique. Lancet $2001 ; 358: 1429$.

9. Xi LF, Koutsky LA, Galloway DA, et al. Genomic varia- tion of human papillomavirus type 16 and risk for high grade cervical intra-epithelial neoplasia. J Natl Cancer Inst 1997;89:796-802.

10. Hildesheim A, Schiffman M, Bromley C, et al. Human papillomavirus type 16 variants and risk of cervical cancer. J Natl Cancer Inst 2001;93:315-8.

11. Ho GY, Burk RD, Klein $S$, et al. Persistent genital human papillomavirus infection as a risk factor for persistent cervical dysplasia. J Natl Cancer Inst $1995 ; 87: 1365-71$.

12. Ho GY, Bierman R, Beardsley L, Chang GJ, Burk RD. Natural history of cervicovaginal papillomavirus infection in young women. N Engl J Med 1998;338:423-8.

13. Koutsky LA, Holmes KK, Critchlow CW, et al. A cohort study of the risk of cervical intraepithelial neoplasia grade 2 or 3 in relation to papillomavirus infection. $\mathrm{N}$ Engl J Med 1992; 327:1272-8.

14. Nobbenhuis MAE, Walboomers JMM, Helmerhorst TJM, et al. Relation of human papillomavirus status to cervical lesions and consequences for cervical-cancer screening: a prospective study. Lancet 1999;324:20-5.

15. Wallin $K L$, Wiklund $F$, Ängström $T$, et al. Type-specific persistence of human papillomavirus DNA before the developments of invasive cervical cancer. N Engl J Med $1999 ; 341: 1633-8$.

16. Franco EL, Villa LU, Sobrinho JP, et al. Epidemiology of acquisition and clearance of cervical human papillomavirus infection in women from a high-risk area for cervical cancer. J Infect Dis $1999 ; 180: 1415-23$.

17. Thomas, KK, Hugues JP, Kuypers JM, et al. Concurrent and sequential acquisition of different genital human papillomavirus types. J Infect Dis 2000;182:1097102 .

18. Liaw $\mathrm{KL}$, Hildesheim $\mathrm{A}$, Burk $\mathrm{RD}$, et al. Prospective study of human papillomavirus (HPV) type 16 DNA detection by polymerase chain reaction and its association with acquisition and persistence of other HPV types. J Infect Dis 2001;183:8-15.

19. Bosch FX, Rohan T, Schneider A, et al. Papillomavinus research update: highlights of the Barcelona HPV 2000 international papillomavirus conference. J Clin Pathol 2001;54:163-75.

20. Schiffman MH, Bauer HM, Hoover RN, et al. Epidemiologic evidence showing that human papillomavirus infection causes most cervical intraepithelial neoplasia. J Natl Cancer Inst 1993; 85:958-64.

21 . Bosch FX, Muñoz N, de Sanjosé S, et al. HPV and CIN III: a case-control study in Spain and Colombia. Cancer Epidemiol Biomarkers Prev 1993;2: 415-22.

22. Olsen AO, Gjoen $K$, Sauer $T$, et al. Human papillomavirus and cervical intraepithelial neoplasia grade II-III: a population-based case-control study. Int $\mathrm{J}$ Cancer $1995 ; 61: 312-5$.

23. Moreno $V$, Muñoz $N$, Bosch $F X$, et al. Risk factors for progression of cervical intraepithelial neoplasm grade III to invasive cervical cancer. Cancer Epidemiol Biomarkers Prev 1995;4:459-67. 
24. Liaw KL, Hsing AW, Chen CJ, et al. Human papillomavirus and cervical neoplasia: a case-control study in Taiwan. Int J Cancer 1995;62:565-71.

25. Kjaer SK, van den Brule $A J$, Bock JE, et al. Human papillomavirus - the most significant risk determinant of cervical intraepithelial neoplasia. Int $J$ Cancer $1996 ; 65: 601-6$.

26. Herrero R, Hildesheim A, Bratti C, et al. Population-based study of human papillomavirus infection and cervical neoplasia in rural Costa Rica. J Natl Cancer Inst $2000 ; 92: 464-74$

27. IARC monographs on the evaluation of carcinogenic risks to humans. Vol. 67. Human immunodeficiency viruses and human T-cell lymohotropic viruses. Lyon: International Agency for Research on Cancer; 1996.

28. Anttila T, Saikku P, Koskela P, et al. Serotypes of Chla-mydia trachomatis and risk for development of cervical squamous cell carcinoma. JAMA 2001; 285:4751.

F. Xavier Bosch José

Servei d'Epidemiologia i Registre del Càncer. Institut Català d'Oncologia.

Hospitalet de Llobregat. Barcelona (Spain) . 